\section{IDENTIFICACIONES DE PLEBEYOS \\ DE COLOR MILITARIZADOS \\ DURANTE LA REVOLUCIÓN DE \\ LA INDEPENDENCIA EN EL RÍO \\ DE LA PLATA. CUYO 1810-1816}

IDENTIFICATIONS OF COLORED MILITARIZED

PLEBEIANS DURING THE REVOLUTION OF

INDEPENDENCE IN THE RIO DE LA PLATA.

CUYO 1810-1816

ORLANDO MORALES •

Orlando Morales es Investigador Asistente del Consejo Nacional de Investigaciones Científicas y Técnicas (CONICET), con sede en el Instituto de

\section{Resumen}

Este trabajo constituye una exploración preliminar de las prácticas de marcación social de alteridad y dinámicas de identificación de los esclavos y la plebe libre de color en la región de Cuyo, durante el período 1810-1860, en el contexto de la militarización por la revolución en el Río de la Plata, por medio de una inmersión antropológica en expedientes judiciales y sumarios militares. La exploración deja ver una persistencia de criterios de estructuración social heredados del período colonial en coexistencia y tensión con nuevos procesos de integración y alterización social. Asimismo, muestra adscripciones plebeyas situacionales e identificaciones dinámicas dentro de límites ajustados por los atributos sociales y las posibilidades surgidas en un contexto de reclutamiento militar generalizado y patriotismo revolucionario.
Ciencias Humanas, Sociales y Ambientales, CONICET CCT Mendoza.

E-mail: omorales@mendoza-conicet.gob.ar

\section{Abstract}

This work constitutes a preliminary exploration of the practices of social marking of alterity and dynamics of identification of slaves and free plebs of color in Cuyo, during the period 18101860 , in the context of militarization by the revolution in the Rio de la Plata, through an anthropological immersion in judicial records and military summaries.

The exploration reveals a persistence of criteria of social structuring inherited from the colonial period in coexistence and tension with new processes of integration and social alteration.

It also shows situational plebeian ascriptions and dynamic identifications within limits adjusted by social attributes and possibilities arising in a context of generalized military recruitment and revolutionary patriotism. 